\title{
Article
}

\section{The Path of Terror Attacks}

\author{
João Ricardo Faria ${ }^{1, *}$ and Daniel Arce ${ }^{2}$
}

1 Department of Economics, Florida Atlantic University, Boca Raton, FL 33431, USA

2 Economics Program, University of Texas at Dallas, Richardson, TX 75080, USA; darce@utdallas.edu

* Correspondence: jfaria@fau.edu; Tel.: +1-(561)-297-2397

\section{check for}

updates

Citation: Faria, J.R.; Arce, D. The Path of Terror Attacks. Games 2021, 12, 35. https://doi.org/10.3390/ g12020035

Academic Editor: Ulrich Berger

Received: 5 March 2021

Accepted: 8 April 2021

Published: 13 April 2021

Publisher's Note: MDPI stays neutral with regard to jurisdictional claims in published maps and institutional affiliations.

Copyright: (C) 2021 by the authors. Licensee MDPI, Basel, Switzerland. This article is an open access article distributed under the terms and conditions of the Creative Commons Attribution (CC BY) license (https:// creativecommons.org/licenses/by/ $4.0 /)$.

\begin{abstract}
This paper derives a dynamic path of ongoing terror attacks as a function of terrorists' capacity and a target government's counterterror capacity. The analysis provides several novel insights and characterizations. First, the effect of counterterror policy is limited. Second, proactive counterterror policy affects the depreciation (fatigue) of terrorists' capacity, and defensive counterterror policy limits the worst-case scenario. Third, fluctuations in the time path of attacks are a function of terrorists' time preferences and adjustment costs of changing tactics, which are policy invariant. Indeed, in our model, the oscillations of terror attacks occur irrespective of the government's counterterror stance. Fourth, collective action inefficiencies associated with the underprovision of proactive counterterror policies and overprovision of defensive ones are further exacerbated by our finding that proactive counterterror policy is the more effective of the two. Hence, the more effective policy is underprovided.
\end{abstract}

Keywords: terror cycles; terror paths; counterterror policy; conflict dynamics; asymmetric conflict

\section{Introduction}

Terrorist attacks follow cyclical paths, in terms of both tactics used and measurable consequences such as casualties (e.g., Enders et al. [1] (1992); Enders and Sandler [2] (2000); Feichtinger et al. [3] (2001); Faria [4] (2003); Das [5] (2008); Feichtinger and Novak [6] (2008)). Knowledge of the path's determinants is essential for designing efficient counterterror policies, since it identifies both the main variables and parameters associated with government counterterror tactics, and the terrorists' rational use of resources, and gives a time horizon for terror campaigns and the duration of terror organizations. We introduce and analyze a game-theoretic dynamic model generating an explicit cyclical path of terror attacks and the time adjustment for changing tactics.

The stocks of terror and counterterror capacities co-determine the outcome of the necessarily asymmetric conflict between terrorists and target government (The concept of an organization's stock of terror capacity abstracts from issues regarding recruitment and training of militants explicitly examined in Faria and Arce [7,8] (2005, 2012a), Calkins et al. [9] (2008), Udwadia, Leitman, and Lambertini [10] (2006), and Faria [11] (2014). Following Kaplan et al. [12] (2005), the stock of terror capacity is a broad notion constituting the human, physical, and monetary resources used to launch terror attacks. "A terror organization's stock of terror capacity can usefully be viewed as an accumulation of the potential to plan and carry out terror attacks" (Keohane and Zeckhauser [13] (2003, p. 204)). Terrorists' threat capacity includes anything of value to the terrorist, including, but not limited to, its organization, its possessions, a physical or nonphysical commodity, and an information set (Hausken [14] (2008)).

The targeted government's interests lie not so much in terrorists' capacity as in eliminating its effects. In Keohane and Zeckhauser [13] (2003), the analysis of terror capacity is multi-period; however, only the government acts, as the stock of terror capacity is assumed to follow Brownian motion with positive drift. In Hausken's [14] (2008) analysis of terrorists' resource capacity, both terrorists and the government interact strategically, albeit 
for two periods. Here, the interaction between terrorists and government is both strategic and ongoing.

Terrorism is a form of asymmetric conflict, with asymmetry appearing in our model in two ways. First, we adopt a Stackelberg or leader-follower framework where the government leads and terrorists follow. Consequently, the target government maximizes its payoff, understanding terrorists' strategy will be a best reply to its counterterror policy. Second, the costs of terror and counterterror actions respect Richardson-Lanchester line-of-fire (in)efficiencies associated with asymmetric dynamic conflict (e.g., Avenhaus and Fichtner [15] (1984); Strickland [16] (2011); MacKay [17] (2015); Kress [18] (2020)). Specifically, terrorists' costs of investing in capacity are a function of their investment only, because terrorists have no problems in identifying or locating the target government. That is to say, the interdependence between terrorists and government does not arise on the cost side of terrorists' payoffs. Instead, government counterterror policy affects the benefit side of terrorists' payoffs by partially determining the probability and consequences of a successful attack. By contrast, the government's costs are proportional to the product of its level of investment and terrorists' capacity because the clandestine nature of terror operations creates an asymmetry in the terrorists' favor. In particular, terrorists must be found before their capacity for terror can be targeted.

\section{The Model}

The model is essentially a stock of (counter)terror capacity competition between the terrorists and targeted government; therefore, the natural framework is dynamic game theory. Define $k$ as the stock of terror capacity and $K$ the stock of counterterror capacity. The stock of terror capacity includes resources terrorists accumulate to support their cause: "a network of supporters; financial capacity; weapons, explosives, and materiel; destructive know-how; a communications network; the tacit approval or even active encouragement of a state or states; trained personnel; and a sufficient number of recruits willing to risk prison or death. The mix of resources may vary greatly from organization to organization, but some accumulated capacity is essential for terror activity" (Keohane and Zeckhauser [13] (2003, pp. 203-4).

For failed states (e.g., Barros et al. [19] (2008) and George [20] (2016)), such as Somalia, $K<k$ holds, while for poor and disorganized regions (e.g., Faria [21] (2008)), such as Russia's interaction with Chechenia, $K \approx k$; for Europe and North America, $K>k$. We focus on the asymmetric case where $K>k$.

\subsection{Deriving the Path of Terrorists' Capacity}

Our solution concept for each period of our infinite horizon game is Stackelberg equilibrium. Dockner et al. [22] (2000, pp. 135-141) provide an overview of this solution. As the follower, in each state, $t$, terrorists observe the government's counterterror strategy. As such, the leader (government) anticipates that the follower selects its best reply to the leader's strategy and the leader maximizes its payoff accordingly. Therefore, we start by analyzing the terrorists' problem first in order to derive the terrorist's best reply to the government's strategy at time $t$.

The terrorists rationally employ their resources to efficiently attack the target government. Function $A(\cdot)$ measures the consequence of terror attacks, including the logistical likelihood of success. Arce [23] (2019) provides measurements of $A(\cdot)$ in terms of disability-adjusted lives lost to terror tactics ranging from suicide bombings to combined firearms/explosives attacks to vehicular assaults. Moreover, the target government's investment in counterterror capacity in the previous period, $\Delta K_{t-1}$, reduces the number or lethality of terror attacks in the current period; i.e., $A(\cdot)$ decreases in $\Delta K_{t-1}$. The benefit portion of the terrorists' payoff therefore takes the form $A\left(\Delta K_{t-1}\right) k_{t}$, where $A^{\prime}\left(\Delta K_{t-1}\right)<0$, and $k_{t}$ is the attack resources stockpiled by terrorists (e.g., Hausken and Zhuang [24,25] 2011a, b). Coefficient $A\left(\Delta K_{t-1}\right)$ on $k_{t}$ indicates the efficacy of the terrorists' stock is a negative function of the government's counterterror policy (Berman and Gavious [26] (2007) analyze a model in which the government chooses cities in which to maximize security, through 
the location choice of facilities that provide support in case of a terrorist attack.). As such, strategic interdependence arises on the benefit side of terrorists' payoffs.

Turning to the terrorists' costs, they face increasing costs of adjusting their stock of terror capacity, an assumption present in dynamic models of capital investment dating back to at least Gould [27] (1968). Hence, $c\left(i_{t}\right), c^{\prime}\left(i_{t}\right)>0$, and $c^{\prime \prime}\left(i_{t}\right)>0$, where $i_{t}$ is the gross investment in $k$. Adjustment costs correspond to the implicit opportunity costs of foregone terrorism owing to the use of an organization's resources to alter its terror capacity. Such a cost structure implies investment in terror capacity can result in a spectacular attack, but the size or number of terrorist attacks is not unlimited. From the perspective of Richardson's [28] (1939) dynamics of conflict, terrorists cannot engage in an arms race with governments.

The rate of change of the stock of terrorists' capacity is given by

$$
\Delta k_{t} \equiv k_{t+1}-k_{t}=i_{t}-\delta k_{t}
$$

where $\delta<1$ is the terrorists' rate of capacity depreciation ("fatigue" in the parlance of Richardson's (1939) conflict dynamics).

We assume the purchase price of a unit of stock of terrorism capacity is constant and equal to 1 . The terrorists' payoff at a point in time is $A\left(\Delta K_{t-1}\right) k_{t}-i_{t}-c\left(i_{t}\right)$. As foreshadowed in the introduction, asymmetric conflict is captured by terrorists' costs being a function of the terrorists' investment, $i_{t}$, and not the counterterror investment of the government, $I_{t}$, or the government's stock of counterterror capacity, $K_{t}$. Moreover, in Richardson-Lanchester approaches to asymmetric dynamic conflict, government targets are "in the open" for terrorists (e.g., MacKay [17] (2015)). By contrast, the government's cost structure, given below, reflects the fact that terrorists are rarely in the open.

The present value of the terrorists' payoffs is

$$
\sum_{t=0}^{\infty} \frac{1}{(1+\tau)^{t}}\left[A\left(\Delta K_{t-1}\right) k_{t}-i_{t}-c\left(i_{t}\right)\right]
$$

where $\tau$ is the terrorists' rate of time preference or its impatience. Terrorists choose the level of investment over time, $i_{t}$, to maximize (2) subject to (1), taking the path of the government's counterterror capacity, $K_{t}$, as given. The Lagrangian, $\mathcal{L}$, for the terrorists' maximization problem is

$$
\mathcal{L}=\sum_{t=0}^{\infty} \frac{1}{(1+\tau)^{t}}\left\{A\left(\Delta K_{t-1}\right) k_{t}-i_{t}-c\left(i_{t}\right)+q_{t}\left[i_{t}+(1-\delta) k_{t}-k_{t+1}\right]\right\}
$$

where the $q_{t}{ }^{\prime} s$ are the Lagrange multipliers corresponding to the identity in Equation (1) for the evolution of the stock of terror capacity, $\Delta k_{t}$, given $i_{t}$ for $t=0,1,2, \ldots, \infty$. We denote the Lagrange multipliers by the lower-case $q$, rather than the more common $\lambda$ or $\mu$, owing to their relationship to Tobin's (marginal) $q$. Tobin's $q$ measures the internal value capacity generates for an organization relative to its replacement cost. When $q>1$, the returns on investment in capacity exceed its costs. Here, $q_{t}$ is the value to the terrorists of an additional unit of capacity at time $t ; q_{t}$ is the shadow price of $\Delta k_{t}$ at the end of period $t$. Note that the constraint is contained within the braces of $\mathcal{L}$, implying shadow prices, $q_{t}, t=0,1,2, \ldots, \infty$, are measured in $t$-period values rather than in present values. Each $q_{t}$ is discounted by $\frac{1}{(1+\tau)^{t}}$ in $\mathcal{L}$.

The first-order conditions for the terrorists with respect to $i_{t}$ are

$$
\frac{\partial \mathcal{L}}{\partial i_{t}}=0 \Longrightarrow q_{t}=1+c^{\prime}\left(i_{t}\right)
$$

For period $t+1$ this is

$$
q_{t+1}=1+c^{\prime}\left(i_{t+1}\right)
$$


Equations (4) and (5) are Tobin's $q$ for terrorists' investment in terror capacity. In the steady state, the value of $q$ corresponds to the cost of acquiring a unit of capacity (fixed at 1) plus marginal adjustment costs. Given the prices of a unit of capacity, $P_{k_{t}}$ and $P_{k_{t+1}}$, the investment rule associated with Tobin's $q$ is as follows: investment takes place, $i_{t}>0$, if $q_{t} / P_{k_{t}}>1$ (similarly, $i_{t+1}>0$ if $q_{t+1} / P_{k_{t+1}}>1$ ). With prices $P_{k_{t}}$ and $P_{k_{t+1}}$ normalized to 1 , Equations (4) and (5) are consistent with the terrorists' positive level of investment in capacity.

The first-order condition for the path of terror capacity is

$$
\frac{\partial \mathcal{L}}{\partial k_{t+1}}=-\frac{1}{(1+\tau)^{t}} q_{t}+\frac{1}{(1+\tau)^{t+1}}\left[A\left(\Delta K_{t}\right)+(1-\delta) q_{t+1}\right]=0
$$

Inserting the values of $q_{t}$ and $q_{t+1}$ from (4) and (5) into this relationship yields

$$
1+c^{\prime}\left(i_{t}\right)=\frac{A\left(\Delta K_{t}\right)+(1-\delta)\left[1+c^{\prime}\left(i_{t+1}\right)\right]}{(1+\tau)}
$$

Equation (7) is the Euler equation for terrorists' capacity investment, capturing the optimal choice between investment today and investment tomorrow when both investments are interior. The terrorists equate the cost of an additional unit of terror capacity in the current period, which is fixed at 1 , plus the adjustment costs, to the discounted value of the sum of (i) the return on increased capacity in the next period, $A\left(\Delta K_{t}\right)$, and (ii) the fatigued (depreciated) unit of additional capacity in the next period, along with the associated savings in adjustment costs. The term $A\left(\Delta K_{t}\right)$ reflects the strategic interdependence of the value of an attack, as it is a function of the government's counterterror policy, $\Delta K_{t}$.

Assuming a simple convex adjustment cost function, $c\left(i_{t}\right)=0.5 c i_{t}^{2}$, from Equations (4), (5), and (7) we have

$$
1+c i_{t+1}=(1-\delta)^{-1}\left[(1+\tau)\left(1+c i_{t}\right)-A\left(\Delta K_{t}\right)\right]
$$

Inserting Equation (1) for $i_{t}=k_{t+1}-k_{t}(1-\delta)$ into (8) yields

$$
k_{t+2}-k_{t+1}=\left[\tau+\delta-\delta c(1-\delta) k_{t+1}+(1+\tau) c\left(k_{t+1}-(1-\delta) k_{t}\right)-A\left(\Delta K_{t}\right)\right]
$$

Equation (9) characterizes the optimal path of terrorists' capacity as a function of the government's counterterror policy, $\Delta K_{t}$.

\subsection{Examining the Government's Counterterror Policy}

We now address the government's problem. Safety from terrorism is a public good, and a government's constituents often hold it accountable for the provision of this public good or lack thereof (Müller [29] (2011); Arce [30] (2020)). Consequently, the government maximizes society's net safety, given by the difference between total safety, $S\left(K_{t}\right)$, and cost term $k_{t} I_{t}$. The product $k_{t} I_{t}$ captures governments' difficulties in targeting terrorists. As terrorists are clandestine by definition, the cost of targeting terrorists is proportional to the stock of terror capacity. Terrorists must be found prior to being targeted, as is the case in models of dynamic conflict where governments "fire blindly" into an "area" defined by $k_{t}$. Kress [18] (2020) calls it, "firing into the brown." By contrast, government targets have to be in the open for terrorism to influence an audience beyond the immediate victims, in agreement with the objective of terrorism in standard definitions of the phenomenon.

The present value of the government's objective function is

$$
\sum_{t=0}^{\infty} \frac{1}{(1+\gamma)^{t}}\left[S\left(K_{t}\right)-k_{t} I_{t}\right]
$$

where $\gamma$ is the government's rate of time preference (impatience). 
In a Stackelberg solution, in each state, $t$, the government takes the terrorists' best reply function, given by Equation (9), and the rate of change of its stock of counterterror capacity:

$$
K_{t}=I_{t}-\bar{\delta} K_{t}
$$

as dynamic constraints. Where, $\bar{\delta}$ is the depreciation rate (fatigue) of the government's stock of counterterror capacity.

The Lagrangian, $\Gamma$, for the government's maximization problem is

$\Gamma=\sum_{t=0}^{\infty} \frac{1}{(1+\gamma)^{t}}\left\{S\left(K_{t}\right)-k_{t} I_{t}+Q_{t}\left[I_{t}+(1-\bar{\delta}) K_{t}-K_{t+1}\right]+\mu_{t}\left[(1+\tau)\left(1+c i_{t}\right)-A\left(\Delta K_{t}\right)-(1+\delta)\left(1+c i_{t+1}\right)\right]\right\}$

where the $Q_{t}{ }^{\prime} s$ are the Lagrange multipliers corresponding to the value to the government of an additional unit of counterterror capacity formation at time $t$, as given in Equation (11). The use of the letter $Q$ for the Lagrange multipliers for the capacity formation constraints in Equation (12) is again as an indicator of the relationship between these Lagrange multipliers and Tobin's marginal $q$ for government investment in counterterror capacity. The $\mu_{t}^{\prime} s$ are the Lagrange multipliers measuring the effect on the government of an additional unit of terrorists' capacity formation by terrorists at time $t$, as given in in Equation (8). As such, the $\mu_{t}{ }^{\prime} s$ are expected to take negative values because additional terror capacity is detrimental to safety. Once again, the Lagrange multipliers, $Q_{0}, Q_{1}, Q_{2}, \ldots ; \mu_{0}, \mu_{1}, \mu_{2}, \ldots$, and associated constraints are measured as $t$-period values (i.e., contained within the braces of $\Gamma$ ). They are discounted each period by $\frac{1}{(1+\gamma)^{t}}$.

The first-order condition for the government's maximization problem with respect to $I_{t}$ is

$$
\frac{\partial \Gamma}{\partial I_{t}}=0 \Rightarrow Q_{t}=k_{t}\left(\Rightarrow \text { for period } t+1: Q_{t+1}=k_{t+1}\right)
$$

Unlike Tobin's $q$ for terrorists, Tobin's $q$ for the government, $Q_{t}$, exhibits strategic interdependence because it is a function of terrorists' current capacity, $k_{t}$. Intuitively, from Equation (13), if $k_{t}=0$ then $Q_{t}=0$ and, by Tobin's $q$, the government does not invest in counterterror capacity: $I_{t}=0$. This is similarly the case for $k_{t+1}, Q_{t+1}$, and $I_{t+1}$. Moreover, by the investment rule for Tobin's $q$, investment takes place only if $Q_{t}>1$. Consequently, if $k_{t}$ is nominal, i.e., $k_{t}<1$, then the government does not invest in counterterror capacity either $\left(k_{t}<1 \Rightarrow Q_{t}<1 \Rightarrow I_{t}=0\right)$, because the government's (shadow) cost of reducing terror capacity exceeds terrorists' current capacity. As a result, small terror groups/capacities fly below the government's radar as they do not trigger a government response. Continuing:

$$
\begin{gathered}
\frac{\partial \Gamma}{\partial i_{t}}=0 \Rightarrow \mu_{t+1}=\frac{(1-\delta)(1+\gamma)}{(1+\tau)} \mu_{t} ; \text { and } \\
\frac{\partial \Gamma}{\partial K_{t+1}}=0 \Rightarrow S^{\prime}\left(K_{t+1}\right)+Q_{t+1}(1-\bar{\delta})+\mu_{t+1}\left(A^{\prime}\left(\Delta K_{t+1}\right)\right)=(1+\gamma)\left[Q_{t}+\mu_{t} A^{\prime}\left(\Delta K_{t}\right)\right]
\end{gathered}
$$

To simplify, we assume safety function $S\left(K_{t}\right)=\bar{S} K_{t}{ }^{\sigma}$. The properties of adjustment costs, $c\left(i_{t}\right)$, allow for spectacular terror attacks, but asymmetry precludes terrorists from engaging in an arms race with the government. As such, let $\bar{A}$ be the maximum potential effect of a terrorist attack, and the parameter $g$ the marginal efficiency of the growth of government's counterterror capacity in curbing terror attacks. It follows that $A\left(\Delta K_{t}\right)=$ $\bar{A}-g \Delta K_{t}$ and $A^{\prime}\left(\Delta K_{t}\right)=-g$. Equation (15) becomes

$$
\sigma \bar{S} K_{t+1}^{\sigma-1}+Q_{t+1}(1-\bar{\delta})-\mu_{t+1} g=(1+\gamma)\left[Q_{t}-\mu_{t} g\right]
$$

\subsection{Elimination of Terrorists' Threat}

Equation (16) can be further reduced by applying $Q_{t}=k_{t}$ and $Q_{t+1}=k_{t+1}$ from Equation (13) and steady-state conditions $K_{t+1}=K_{t}=K^{*} ; \mu_{t+1}=\mu_{t}=\mu^{*}$. As discussed 
above, $\mu^{*}$ must be negative, since an increase in the terror capacity must decrease the optimal value of the government's objective function. Without loss of generality, let $\mu^{*}=-1$.

Our first major result is highlighted by the following proposition:

Proposition 1. Only governments who are more impatient than terrorists (i.e., $\gamma>\tau)$ find it in their interests to attempt to fully eliminate terrorists' capacity.

Proof of Proposition 1. The long-run equilibrium level of $K^{*}$ necessary to fully eliminate terrorists' capacity, i.e., the value of $K^{*}$ yielding $k=0$, is obtained from Equation (16) in the steady state and is given by:

$$
K_{k=0}^{*}=\left(\frac{\sigma \bar{S}}{g \gamma}\right)^{\frac{1}{1-\sigma}}
$$

For an interior solution, $K_{k=0}^{*}>0$, by Equation (14), the steady state where $\mu_{t+1}=$ $\mu_{t}=\mu^{*}$ yields $\frac{1+\tau}{1+\gamma}=1-\delta<1$. Consequently, only governments who are more impatient than terrorists (i.e., $\gamma>\tau$ ) find it in their interests to attempt to fully eliminate terrorists capacity.

Yet, it unlikely that targeted governments are less impatient than terrorists because the lifespan of terrorist organizations is relatively short (Vittori [31] (2009; Faria and Arce [32] (2012b); Gaibulloev and Sandler [33] (2013)). Consequently, when governments are the more patient of the two, they do not find it optimal to set $K^{*}$ such that $k=0$. Instead, patient governments treat terrorism as an ongoing phenomenon. The ongoing interaction between governments and terrorists is the subject of the following section.

\section{Ongoing Terrorism and the Dynamic Path of Terror Capacity}

An ongoing terrorist threat occurs when the government is more patient than terrorists. In order to characterize the dynamic path of terror capacity, we analyze the terrorists' (follower's) response by substituting Equation (17) into Equation (9). From Equation (11), when $I_{t} \neq K_{k=0}^{*}$, terrorists' capacity follows the following dynamic path:

$k_{t+2}-k_{t+1}=[c(1-\delta)]^{-1}\left[\tau+\delta-\delta c(1-\delta) k_{t+1}+(1+\tau) c\left(k_{t+1}-(1-\delta) k_{t}\right)-\bar{A}+g\left(I_{t}-\bar{\delta} K^{*}\right)\right]$

The presence of terms $k_{t+2}, k_{t+1}$, and $k_{t}$ in Equation (18) implies the path of terrorists' capacity is a second-order linear difference equation. Solving the equation involves dividing it into two parts: a particular solution and a homogenous solution. We begin by deriving a solution particular to the steady state: $k_{t+2}=k_{t+1}=k_{t} \neq 0$. The particular solution, $k_{p}$, is

$$
k_{p}=\left(\frac{\bar{A}-g\left(I_{t}-K^{*}\right)-\tau-\delta}{c \delta(\tau+\delta)}\right)
$$

The second part of the solution to Equation (18) is the homogenous solution, so named because it corresponds to the case where the constant term in Equation (18), $\bar{A}-g\left(I_{t}-K^{*}\right)-$ $\tau-\delta$, is zero. The trivial solution takes the form $k_{t+2}=k_{t+1}=k_{t}=0$. The nontrivial solution is typically derived by assuming the homogenous solution takes the same form as the solution to a first-order difference equation: $k_{t}=\lambda^{t}$, where $\lambda \neq 0$ is an unknown constant interpreted as an eigenvalue (characteristic root). Setting $\bar{A}-g\left(I_{t}-K^{*}\right)-\tau-\delta=0$ and substituting $k_{t}=\lambda^{t}$ into Equation (18) gives the following:

$$
\lambda^{t}\left[\lambda^{2}-\left(1-\delta+\frac{1+\tau}{1-\delta}\right) \lambda+(1+\tau) c\right]=0
$$


where the term in brackets is the characteristic equation for Equation (18). The homogeneous solution has two roots:

$$
\begin{aligned}
& \lambda_{1}=\frac{\left(1-\delta+\frac{1+\tau}{1-\delta}\right)+\sqrt{\left(\delta-1-\frac{1+\tau}{1-\delta}\right)^{2}-4(1+\tau) c}}{2} \\
& \lambda_{2}=\frac{\left(1-\delta+\frac{1+\tau}{1-\delta}\right)-\sqrt{\left(\delta-1-\frac{1+\tau}{1-\delta}\right)^{2}-4(1+\tau) c}}{2}
\end{aligned}
$$

As $\delta$ is the rate of terror capacity depreciation (fatigue), it follows that $\delta<1$ and both roots are complex. The complex roots can be written as conjugate pairs $\lambda_{1}=\alpha+i \beta$ and $\lambda_{2}=\alpha-i \beta$, where, from Equation (20), $\alpha=\frac{\left(\delta-1-\frac{1+\tau}{1-\delta}\right)}{2}$ and $\beta=\frac{\sqrt{4(1+\tau) c-\left(\delta-1-\frac{1+\tau}{1-\delta}\right)^{2}}}{2}$. The complex conjugate pairs correspond to the solutions $k_{t}=\lambda_{1}^{t}=(\alpha+i \beta)^{t}$ and $k_{t}=\lambda_{2}^{t}=$ $(\alpha-i \beta)^{t}$. Adopting polar representations, $\lambda_{1}=\alpha+i \beta=\sqrt{\alpha^{2}+\beta^{2}} \cdot(\cos \theta+i \sin \theta)$ and $\lambda_{2}=\alpha-i \beta=\sqrt{\alpha^{2}+\beta^{2}} \cdot(\cos \theta-i \sin \theta)$, where $\sin \theta=\frac{\beta}{\sqrt{\alpha^{2}+\beta^{2}}}$ and $\cos \theta=\frac{\alpha}{\sqrt{\alpha^{2}+\beta^{2}}}$.

For these complex roots, the two corresponding homogenous solutions, $k_{h}^{(1)}$ and $k_{h}^{(2)}$, are

$$
k_{h}^{(1)}=(\sqrt{(1+\tau) c})^{t}(\cos \theta t+i \sin \theta t) \text { and } k_{h}^{(2)}=(\sqrt{(1+\tau) c})^{t}(\cos \theta t-i \sin \theta t)
$$

By the superposition principle, if $k_{h}^{(1)}$ and $k_{h}^{(2)}$ are solutions to a homogenous difference equation, then so is

$$
k_{h}=C_{1} k_{h}^{(1)}+C_{2} k_{h}^{(2)}
$$

where $C_{1}$ and $C_{2}$ are arbitrary constants.

Since $k_{t}$ must be a real number, the homogenous solution must be a real number. As $k_{h}^{(1)}$ and $k_{h}^{(2)}$ are imaginary, then it must be the case that $C_{1}$ and $C_{2}$ are imaginary as well. Hence, $C_{1}$ and $C_{2}$ can also be expressed as complex conjugates:

$$
C_{1}=\hat{\alpha}+i \hat{\beta}=\sqrt{\hat{\alpha}^{2}+\hat{\beta}^{2}} \cdot(\cos \theta+i \sin \theta) ; C_{2}=\hat{\alpha}-i \hat{\beta}=\sqrt{\hat{\alpha}^{2}+\hat{\beta}^{2}} \cdot(\cos \theta-i \sin \theta)
$$

By substituting these values for $C_{1}$ and $C_{2}$ into Equation (24), Goldberg [34] (1986, p. 140) provides the steps for reducing Equation (24) to

$$
k_{h}=2 \hat{C}_{1}(\sqrt{(1+\tau) c})^{t} \cos \left(\theta t+\hat{C}_{2}\right)
$$

where $\hat{C}_{1}$ and $\hat{C}_{2}$ are arbitrary real constants and $\theta$ is the same as before. Interestingly, the homogenous solution depends only on the terrorists' impatience, $\tau$, and adjustment costs, $c$.

We now present the main result characterizing the dynamic path of terrorists' capacity accumulation. The complete solution for the path of terrorists' capacity requires combining the homogenous solution, $k_{h}$, with the particular solution, $k_{p}$ (Intuitively, if $k_{t}$ and $k_{p}$ are solutions to a difference equation with nonzero constant term, then $k_{t}-k_{p}$ is a solution to the homogenous version of the difference equation). That is, $k_{t}=k_{h}+k_{p}$, yielding

$$
k_{t}=2 \hat{C}_{1}(\sqrt{(1+\tau) c})^{t} \cos \left(\theta t+\hat{C}_{2}\right)+\underbrace{\left(\frac{\bar{A}-g\left(I_{t}-K^{*}\right)-\tau-\delta}{c \delta(\tau+\delta)}\right)}_{k_{p}}
$$

As the cosine function oscillates, the path of terror capacity exhibits a fluctuating pattern periodic in nature. The path is a stepped fluctuation of discrete points (it is 
only smooth for continuous time), oscillating between values above and below $k_{p}=$ $\left(\frac{\bar{A}-g\left(I_{t}-K^{*}\right)-\tau-\delta}{c \delta(\tau+\delta)}\right)$. What matters in our context is convergence, as determined by the term $(\sqrt{(1+\tau) c})^{t}$. Three possibilities emerge.

Case 1: $\sqrt{(1+\tau) c}>1$. Here, $k_{t}$ oscillates with ever-increasing amplitude, implying a divergent and explosive path of terrorists' capacity accumulation. Such an outcome is not possible because terrorists' limited resources are the defining feature of terrorism as asymmetric conflict; i.e., $K_{t} \gg k_{t}$. Alternatively, for the situation of failed states, $K_{t}<k_{t}$, this case identifies when terrorists win.

Case 2: $\sqrt{(1+\tau) c}=1$. The solution is an equilibrium solution. Here, $k_{t}$ oscillates (about $k_{p}$ ) with constant amplitude.

Case 3: $\sqrt{(1+\tau) c}<1$. Here, $k_{t}$ oscillates with monotonic-decreasing amplitude and converges to $k_{p}$ as $t \rightarrow \infty$. This holds iff $c<\frac{1}{1+\tau}$.

Cases 2 and 3 are relevant for the present study because terrorists generally do not have the resources to engage in an arm's race with targeted governments. Several novel observations arise from the characterization of the dynamics of the capacity accumulation path given in Equation (27). First, $c \leq \frac{1}{1+\tau}$ relates terrorists' adjustment (opportunity) cost of investing in new terror capacity (foregone terrorism) to terrorists' discount factor. In particular, patient terrorists can exhibit a variety of tactics over their lifespan because their patience (low $\tau$ ) allows for the associated higher adjustment costs. By contrast, impatient terrorists will not forestall attacks in order to accommodate the adjustment costs associated with a portfolio of tactics. No direct counterterror policy prescription follows from the $c \leq \frac{1}{1+\tau}$ characterization, as neither $\tau$ nor $c$ are policy variables. They are, instead, the terrorists' primitives. Impatience term $\tau$ stems from the terrorists' time preferences, and counterterror policy has no effect on adjustment costs, $c$, which are measured in terms of the attacks terrorists are willing to forgo to adjust their stock of terror capacity.

Second, a lull in terror activity need not be indicative of successful counterterror policy. Instead, it can be due to patient terrorists undergoing the adjustment costs associated with a forthcoming wave of new tactics. For example, Enders and Sandler [2] (2000, p. 323) employ time series analysis to show that "authorities should focus on anticipating upturns in incidents involving casualties following fairly length lulls of greater than two years". Moreover, the authors identify the period immediately prior to the yet-to-occur events of September 11, 2001 as being the longest lull on record. The tactical innovation of simultaneous coordinated skyjackings to employ airliners as weapons during $9 / 11$ reveals Al Qaeda's willingness to undertake the adjustment costs stemming from its meticulous preparations prior to the attacks. By contrast, the spate of vehicular assaults incited by ISIS during the late 2010's required little in the way of adjustment costs; as instructions were distributed online, many of the vehicles were stolen or rented, and the operatives were at arms-length (Siqueira and Arce [35] 2020).

Proposition 2. Fluctuations in the time path of attacks are a function of terrorists' time preferences and adjustment costs of changing tactics, which are policy-invariant.

Proof of Proposition 2. The government has no control over the oscillatory component of the time path of terrorism, as the terms surrounding the cosine function in Equation (27), $c$ and $\tau$, are the terrorists' primitives.

Fourth, the time path characterized in Equation (27) is akin to a time-variant system with $k_{p}$ as the input and $k_{t}$ the output. This begs the question as to the government's degree of control (over $k_{p}$ ). In the steady state (i.e., $\Delta K_{t}=0 \Rightarrow I_{t}=K^{*}$ ), $k_{p}$ reduces to

$$
k_{p}^{*}=\frac{\bar{A}-\tau-\delta}{c \delta(\tau+\delta)}
$$


Counterterror policies traditionally fall into two broad categories: proactive and defensive (e.g., Frey [36] (2004); Arce and Sandler [37] (2005); Sandler and Siqueira [38] (2006); Bandyopadhyay and Sandler [39] (2011); Bier and Hausken [40] (2011)). Proactive policies include attacking terrorists' training grounds and freezing the assets of supporting organizations. Proactive policies directly target the stock of terror assets, i.e., they increase fatigue term $\delta$. By contrast, defensive policies, such as hardening targets and controlling the inflow of potential terrorists' immigrants or refugees, limit the upper bound on terrorists' capacity, $\bar{A}$ (For alternatives to defensive strategies see (Frey and Luechinger [41] 2003)). Moreover, the literature on the collective action problems associated with proactive and defensive policies most often treats terrorists as a passive third party. Equation (28) provides the direct link between proactive and defensive counterterror policies and the actions of terrorists themselves. In particular, $k_{p}=0$ when the mix of defensive and proactive counterterror policies satisfies $\bar{A}-\delta=\tau$. Counterterror policy is formulated with reference to terrorists' impatience. Under these circumstances, terrorists' capacity is not zero but instead oscillates about $k_{p}=0$ if the government has the requisite winningness, resources, intelligence, etc., to set $\bar{A}-\delta=\tau$ by decreasing $\bar{A}$ via defensive policy and increasing $\delta$ via proactive policy.

Fifth, in the absence of the requirements sufficient to set $\bar{A}-\delta=\tau$, government control over the time path of terror capacity via counterterror policy is characterized by

$$
\begin{gathered}
\frac{\partial k_{p}^{*}}{\partial \bar{A}}=\frac{1}{c \delta(\tau+\delta)} \\
\frac{\partial k_{p}^{*}}{\partial \delta}=\frac{-c \delta(\tau+\delta)-(\bar{A}-\tau-\delta)[c(\tau+\delta)+c \delta \tau]}{[c \delta(\tau+\delta)]^{2}}
\end{gathered}
$$

An increase in defensive counterterror policy decreases $\bar{A}$, leading to a decrease in the stock of terror capacity given by Equation (29). Similarly, an increase in proactive counterterror policy increases $\delta$, leading to a decrease in the stock of terror capacity given by Equation (30).

Sixth, from the perspective of international collective action and the coordination of counterterror policy (e.g., Faria et al. [42] 2020), defensive counterterror policies are strategic complements and proactive ones are strategic substitutes (Sandler and Siqueira [38] (2006); Faria et al. [43] (2017).) Accordingly, governments overuse defensive policies and underprovide proactive ones. The characterizations given in Equations (29) and (30) shed further light on these inefficiencies, giving rise to the following proposition.

Proposition 3. Proaction is both underprovided and more effective compared with defensive counterterror policy.

Proof of Proposition 3. From Equations (29) and (30), $\left|\frac{\partial k_{p}^{*}}{\partial \delta}\right|>\left|\frac{\partial k_{p}^{*}}{\partial \bar{A}}\right|$.

Corollary. At the same time, neither proactive nor defensive counterterror policies affect the ebb and flow of terrorists' actions; the amplitude of terrorism is determined by terrorists' primitives $c$ and $\tau$. Hence, the fluctuations in our model are consistent with terrorists deliberately undertaking what appear to be uncertain (time-variant) actions on their part.

\section{Conclusions}

This paper considers a dynamic game of terror and counterterror capacity accumulation between terrorists and a target government in order to provide a full characterization of their ongoing asymmetric conflict in terms of the time path of terrorists' capacity. The term "ongoing conflict" is used because the necessary condition for governments' willingness to attempt to fully eliminate terrorists' capacity is for the government to be more 
impatient than the terrorists. As it is well known that terrorist groups are short-lived relative to their target governments (excluding failed or organizationally disadvantage states), the necessary condition on relative time preferences is unlikely to be met. Consequently, targeted governments purposefully treat terrorism as an ongoing phenomenon.

Within this context, an advantage of dynamic models producing time paths of terror activity is they can be "tested, evaluated, and improved upon through the use of actual field data" (Strickland [16] (2011, p. 161)). While such an exercise is a future research direction, it is beyond the scope of the present analysis.

At the same time, the analysis provides several novel insights. For example, governments' resignation to terrorism's persistence is not akin to an "optimal negative externality" argument, such as occurs for pollution abatement. In the case of pollution abatement, the presence of diminishing marginal social benefits and increasing marginal social costs leads to a positive level of (optimal) pollution (Mishan [44] 1974). By contrast, only the base accumulation of terror capacity around which oscillations occur is determined by policy. We characterize how proactive counterterror capacity affects the depreciation (fatigue) of terrorists' capacity and how defensive counterterror policy limits the worst-case scenario. The effectiveness of such policies is a function of terrorists' primitives (time preferences and adjustment costs of changing tactics), which are policy-invariant.

Accordingly, the effect of counterterror policy is limited. Oscillations in the time path of terror capacity are a function of terrorists' primitives. Consequently, the amplitude of terrorism only converges to zero in the long run. Once again, such dampening is determined by terrorists' primitives, rather than counterterror policy. As such, terrorists willingness to make the impatience-adjustment cost tradeoff is the root determinant of their longevity.

Counterterror policy is therefore plagued by inefficiencies and paradoxes. The ebb and flow of terror tactics results from terrorists trading impatience for improved tactics and their associated adjustment costs. Such lulls in activity and changes in tactics are observationally equivalent to terrorists substituting tactics in response to defensive counterterror policies (e.g., security screening in airports) and yet they may have absolutely nothing to do with counterterror tactics. Indeed, in our model, the oscillations occur irrespective of the government's counterterror stance. In addition, collective action inefficiencies associated with the underprovision of proactive counterterror policies and overprovision of defensive ones are further exacerbated by our finding that proactive counterterror policy is the more effective of the two. Hence, the more effective policy is underprovided. This is a novel characterization of counterterror policy relative to the extant literature.

Author Contributions: Conceptualization, J.R.F. and D.A.; methodology, J.R.F.; formal analysis, J.R.F. and D.A.; investigation, J.R.F. and D.A.; writing-original draft preparation, J.R.F.; writing-review and editing, D.A. All authors have read and agreed to the published version of the manuscript.

Funding: This research received no external funding.

Institutional Review Board Statement: Not applicable.

Informed Consent Statement: Not applicable.

Conflicts of Interest: The authors declare no conflict of interest.

\section{References}

1. Enders, W.; Parise, G.; Sandler, T. A Time-Series Analysis of Transnational Terrorism: Trends and Cycles. Def. Econ. 1992, 3, 305-320. [CrossRef]

2. Enders, W.; Sandler, T. Is Transnational Terrorism Becoming More Threatening? A Time Series Investigation. J. Confl. Resolut. 2000, 44, 307-332. [CrossRef]

3. Feichtinger, G.; Hartl, R.; Kort, P.; Novak, A.J. Terrorism Control in the Tourism Industry. J. Optim. Theory Appl. 2001, 108, 283-296. [CrossRef]

4. Faria, J.R. Terror Cycles. Stud. Nonlinear Dyn. Econom. 2003, 7, 3. [CrossRef]

5. Das, S.P. Some Mechanisms of Terror Cycles. J. Econ. Behav. Organ. 2008, 67, 644-656. [CrossRef] 
6. Feichtinger, G.; Novak, A. Terror and Counterterror Operations: Differential Game with Cyclical Nash Solution. J. Optim. Theory Appl. 2008, 139, 541-556. [CrossRef]

7. Faria, J.R.; Arce, D. Terror Support and Recruitment. Def. Peace Econ. 2005, 16, 263-273. [CrossRef]

8. Faria, J.R.; Arce, D. Counterterrorism and Its Impact on Terror Support and Recruitment: Accounting for Backlash. Def. Peace Econ. 2012, 23, 431-445. [CrossRef]

9. Caulkins, J.P.; Grass, D.; Feichtinger, G.; Tragler, G. Optimizing Counter-Terror Operations: Should One Fight Fire With "Fire" or "Water"? Comput. Oper. Res. 2008, 35, 1874-1885. [CrossRef]

10. Udwadia, F.; Leitmann, G.; Lambertini, L. A Dynamical Model of Terrorism. Discret. Dyn. Nat. Soc. 2006, 2006, 085653. [CrossRef]

11. Faria, J.R. The Economics of Technology in Terror Organizations. Brown J. World Aff. 2014, 20, $285-296$.

12. Kaplan, E.H.; Mintz, A.; Mishal, S.; Samban, C. What Happened to Suicide Bombings in Israel? Insights from a Terror Capacity Model. Stud. Confl. Terror. 2005, 28, 225-235. [CrossRef]

13. Keohane, N.O.; Zeckhauser, R.J. The Ecology of Terror Defense. J. Risk Uncertain. 2003, 26, 201-229. [CrossRef]

14. Hausken, K. Whether to Attack a Terrorist's Resource Capacity Today or Tomorrow. Games Econ. Behav. 2008, 64, 548-564. [CrossRef]

15. Avenhaus, R.; Fichtner, J. A Review of Richardson Models. In Quantitative Assessment in Arms Control; Avenhaus, R., Huber, R.K., Eds.; Springer: Boston, MA, USA, 1984; pp. 143-177.

16. Strickland, J. Mathematical Modeling of Warfare and Combat Phenomenon; Simulation Educators: Colorado Springs, CO, USA, 2011.

17. Mackay, N.J. When Lanchester Met Richardson, the Outcome Was Stalemate: A Parable for Mathematical Models of Insurgency. J. Oper. Res. Soc. 2015, 66, 191-201. [CrossRef]

18. Kress, M. Lanchester Models for Irregular Warfare. Mathematics 2020, 8, 737. [CrossRef]

19. Barros, C.P.; Faria, J.R.; Gil-Alana, L. Terrorism in Africa: Persistence and Poverty. J. Policy Model. 2008, 30, 55-69. [CrossRef]

20. George, J. State Failure and Transnational Terrorism: An Empirical Analysis. J. Confl. Resolut. 2016, 92, 471-495. [CrossRef]

21. Faria, J.R. Public Support and Terrorism: The Putin Paradox. Open Political Sci. J. 2008, 1, 1-4. [CrossRef]

22. Dockner, E.J.; Jorgensen, S.; Van Long, N.; Sorger, G. Differential Games in Economics and Management Science; Cambridge University Press (CUP): Cambridge, UK, 2000.

23. Arce, D. On the Human Consequences of Terrorism. Public Choice 2019, 178, 371-396. [CrossRef]

24. Hausken, K.; Zhuang, J. Defending Against a Terrorist Who Accumulates Resources. Mil. Oper. Res. 2011, 16, 21-39. [CrossRef]

25. Hausken, K.; Zhuang, J. Defending Against a Stockpiling Terrorist. Eng. Econ. 2011, 56, 321-353.

26. Berman, O.; Gavious, A. Location of Terror Response Facilities: A Game between State and Terrorist. Eur. J. Oper. Res. 2007, 177, 1113-1133. [CrossRef]

27. Gould, J.P. Adjustment Costs in the Theory of Investment of the Firm. Rev. Econ. Stud. 1968, 35, 47-55. [CrossRef]

28. Richardson, L.F. Generalized Foreign Politics. In British Journal of Psychology; Monograph Supplements, No. XXIII; Cambridge University Press: Cambridge, UK, 1939.

29. Müller, C. The Economics of Terrorism from a Policy-Maker's Perspective. Def. Peace Econ. 2011, 22, 125-134. [CrossRef]

30. Arce, D. On the Calculus of Counterterror Policy. Def. Peace Econ. 2020, 31, 387-399. [CrossRef]

31. Vittori, J. All Struggles Must End: The Longevity of Terrorist Groups. Contemp. Secur. Policy 2009, 30, 444-466. [CrossRef]

32. Faria, J.R.; Arce, D. A Vintage Model of Terror organizations. J. Confl. Resolut. 2012, 56, 629-650. [CrossRef]

33. Gaibulloev, K.; Sandler, T. Determinants of the Demise of Terrorist Organizations. South. Econ. J. 2013, 79, 774-792. [CrossRef]

34. Goldberg, S. Introduction to Difference Equations; Dover: London, UK, 1986.

35. Siqueira, K.; Arce, D. Terrorist Training: Online or Via the Internet? Eur. J. Political Econ. 2020, 63, 101878. [CrossRef]

36. Frey, B.S. Dealing with Terrorism: Stick or Carrot? Foreign Aff. 2004, 84, 181. [CrossRef]

37. Arce, D.; Sandler, T. Counterterrorism. A Game-Theoretic Analysis. J. Confl. Resolut. 2005, 49, $183-200$.

38. Sandler, T.; Siqueira, K. Global terrorism: Deterrence versus Pre-emption. Can. J. Econ. Rev. Can. D'économique 2006, 39, 1370-1387. [CrossRef]

39. Bandyopadhyay, S.; Sandler, T. The Interplay between Preemptive and Defensive Counterterrorism Measures: A Two-Stage Game. Economica 2009, 78, 546-564. [CrossRef]

40. Bier, V.; Hausken, K. Endogenizing the Sticks and Carrots: Modeling possible perverse effects of counterterrorism measures. Ann. Oper. Res. 2011, 186, 39-59. [CrossRef]

41. Frey, B.S.; Luechinger, S. How to Fight Terrorism: Alternatives to Deterrence. Def. Peace Econ. 2003, 14, 237-249. [CrossRef]

42. Faria, J.R.; Novak, A.; Bagchi, A.; Mathews, T. The Refugee Game: The Relationship between Individual Security Expenditures and Collective Security. Games 2020, 11, 24. [CrossRef]

43. Faria, J.R.; Silva, E.; Arce, D.G. Intertemporal Versus Spatial Externalities in Counterterror Policy Games. Dyn. Games Appl. 2017, 7, 402-421. [CrossRef]

44. Mishan, E.J. What Is the Optimal Level of Pollution? J. Political Econ. 1974, 82, 1287-1299. [CrossRef] 